\title{
CASE OF FREDERIC CHOPIN: COULD MUSIC BE A SYMPTOM? ${ }^{1}$ Berezutsky V. I., ${ }^{2}$ Berezutskaya M. S.
}

${ }^{1}$ Dnepropetrovsk Medical Academy of Health Ministry of Ukraine, Dnipro, Ukraine ${ }^{2}$ Glinka Dnipropetrovsk Academy of Music, Dnipro, Ukraine

The mystery of the illness and death of the great Polish composer Frederic Chopin not yet solved finally. Numerous attempts of retrospective diagnostics used all available possibilities except for analyzing the music of the composer to search for the manifestations of his disease in it. There are many examples in the history of medicine that music may contain valuable diagnostic information about the author's illness.

Aim. Purpose of this study is searching for signs of the manifestation of Chopin's disease in his musical works and to get an answer to the question: can his music contain valuable data for diagnostics.

Material and methods. The Frederic Chopin's correspondence, the work of the composer's most respected biographers, as well as scientific publications devoted to the study of the circumstances of Chopin's life, illness and work. Scopus, WebOfScience, MedLine and PubMed databases were searched without time restriction. Discovered publications were subjected to medical and musicological analysis.

Conclusions. Analysis shows that Chopin's creative process did not depend on the circumstances of his personal life, nor on his health. The composer did not write program music, never supplied his works with comments and did not apply sound imitation by musical means. None of the hypotheses that coughing attacks are reflected in Chopin's music has been confirmed. Analysis of Chopin's music as a component of professional anamnesis does not provide additional information for diagnosis.

Keywords: Frederic Chopin, anamnestic diagnostic, retrospective diagnostic

For citation: Berezutsky VI, Berezutskaya MS. Case of Frederic Chopin: could music be a symptom? Journal of the Grodno State Medical University. 2020;18(2):211-216. http://dx.doi.org/10.25298/2221-8785-2020-18-2-211-216

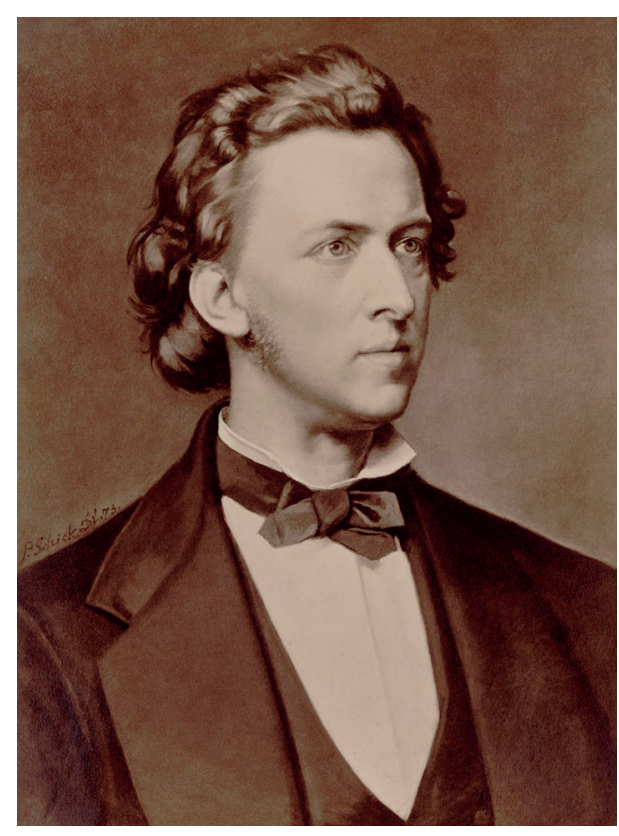

Introduction

2019 marked 170 years since the death of the greatest Polish composer of all time, Frederic Chopin. For all this time, the mystery of the illness and death of the composer's have not buggin rest to scientists, attempts at retrospective diagnosis have not been stopping for a single year. In the course of a thorough analysis of all available documents (F. Chopin's letters and his close, the memoirs of numerous physicians and the composer's contemporaries), were formulated the main diagnostic hypotheses for the diagnosis: tuberculosis [1], cystic fibrosis [2] and alpha 1-antitrypsin defciency [3]. Most researchers speak about such a diagnosis as tuberculosis. Recent attempts to revise the medical history of Frederick Chopin, made in 2018, confirm this assumption, albeit with certain reservations. Researcher Victoria Wapf, M.D. from University of Bern (Switzerland) performed a largescale study based on an analysis of more than 200 sources, and came to the following conclusion: "The total body of evidence gathered from the current and historical literature allows for a strong presumption of tuberculosis as Chopin's diagnosis. However, other primary diagnoses, comorbidities, as well as consequences of an iatrogenic exposure should still be regarded and may not be fully discounted" [4]. An interdisciplinary team of Polish scientists, based on the results of a visual study of F. Chopin's heart, stored in Holy Cross Church (Kosciol Swietego Krzyza) from the day of the composer's death, came to the following conclusion: "The myocardial lesions found on a Chopin's heart, i.e., tuberculomas and fibrinous pericarditis ... most likely result from mycobacterial infection of the whole heart. Although chronic ... tuberculosis is the most plausible diagnosis of Frederic Chopin, only an analysis of the remains of the members of the Chopin family ... might shed light on infectious and/or genetic factors present in Chopin's family" [5]. However, even these very cautious conclusions were immediately questioned and criticized $[6,7]$.

It would seem that the possibilities of retrospective diagnosis of Chopin's disease are completely exhausted and further progress is impossible. However, analysis of numerous pathographic studies from the standpoint of classical (propaedeutic) diagnostics reveals that the composer's professional anamnesis was used only partially (in terms of impacts on creative activity) [8, $9,10]$. The musical works of Chopin as a possible 
source of signs of the composer's illness have not yet been used in pathographic studies. While the music often contains a wide range of information about the diseases of their authors. Retrospective diagnostics specialists are cautious about the use of works of art as diagnostic signs of diseases of their creators due to the difficulty of interpretation. Correct extraction of medical information from music is possible only with an interdisciplinary approach using musicological analysis. Nevertheless, from the standpoint of classical diagnostics, the works of composers (as a product of their creative activity) are part of their professional anamnesis, so they are not just possible, but need to be analyzed when making a diagnosis. There are many examples in the history of medicine that music may contain valuable diagnostic information.

Intentional musicification of cardiac arrhythmia was discovered in Ludwig van Beethoven [11] and Gustav Mahler [12], bronchospastic syndrome - in Giacomo Rossini (1792-1868) and Marin Marais (1656-1728) [13]. One of the pieces by Marin Marais is a musical illustration of an operation to remove a stone from the bladder. The composer provided the score with chilling comments [14]. One of Ludwig van Beethoven's compositions (the slow movement of the String Quartet No. 15 in A-minor, Op. 132) subtitled the "Heiliger Dankgesangeines Genesenen" ("A Convalescent's Holy Song of Thanks"), quartet was written upon his recovery from a near fatal episode of intestinal inflammation in the winter of 1825 . In the music of composers was found the reflection of their neurological [15] and psychiatric disorders [16].

If additional information about diseases was found in the music of Beethoven, Schumann, Rossini, Mahler, Ravel and other composers, why can't it be in the Chopin's music? Everyone is convinced that the long-term progressive disease of Chopin influenced his music: biographers - contemporaries of the composer, musicologists and physicians. The famous composer Franz Liszt, a close friend of Chopin expressed a general opinion:"Chopin was a victim to a disease without hope, which growing more envenomed from year to year, took him, while yet young, from those who loved him, and laid him in his still grave. As in the fair form of some beautiful victim, the marks of the grasping claws of the fierce bird of prey which has destroyed it, may be found; so, in the productions ... the traces of the bitter sufferings which devoured his heat, and painfully visible" [17, p. 33]. The purpose of this study is to identify the "marks of the grasping claws" of Chopin's disease in his music. Musical works (even written 200 years ago) are preserved much better than any historical documents. The detection of the manifestations of the disease in the music of the composer seems to be a quite feasible task, since all the works of F. Chopin are thoroughly analyzed by musicologists; the history of their creation is well known. Establishing a chronological and causal relationship between the direct or indirect signs of the disease (professional history), the circumstances of their creation (history of life) and the composer's health status (history of the disease) identified in
F. Chopin's music can contribute to the differential diagnosis.

\section{The aim}

This study is not another attempt to retrospective diagnostic. Its purpose is searching for signs of the manifestation of Chopin's disease in his musical works and to get an answer to the question: can his music contain valuable data for diagnostics.

\section{Material and methods}

The main material for the study was the Frederic Chopin's letters, the work of the composer's most respected biographers, as well as scientific publications by musicologists and specialists in retrospective diagnostics (devoted to the study of the circumstances of Chopin's life, illness, and work). To achieve the goal of study, a search was made for sources in scientometric databases Scopus, WoS, Medline, Med Pub, Google Scholar, Copernicus, CrossRef, International Index to Music Periodicals; The Music Index; Abstracts of Music Literature Humanities International Index; International Index to Music Periodicals (without any time restrictions). Keyword combinations were used: Frederic Chopin's biography, Frederic Chopin's illness, Frederic Chopin's disease, Frederic Chopin's music. The search was conducted for sources in English, Polish, French, German, Russian and Spanish. A total of 289 publications were found, 30 of which were directly used in the present study. Discovered publications were subjected to medical and musicological analysis.

\section{Results and discussion}

Author of numerous works on retrospective diagnostic, professor at the Institute for the History of Medicine and Medical Ethics in Cologne (Germany) Axel Karenberg by the case of Frederic Chopin's medical biography systematized the problems that arise during the reconstruction of the medical history 200 years ago: loss of medical records and other important documents, the imperfection of the then medicine, biased eyewitness accounts, falsification of documents, errors in translating the content of documents from one language to another, etc. [18]. These problems determined the impossibility of justifying a reliable diagnosis in the case of F. Chopin. The autopsy was performed by last physician of Chopin professor Jean Cruveilhier (1791-1874), a distinguished Paris pathologist (first Chair of Pathology in Paris). He issued the death certificate and wrote the medical report, but both these documents are missing. The letters to George Sand, with whom the life of F. Chopin was closely associated for 7 years, have been lost. Chopin's letters to the Delfina Potocka turned out to be skillful forgeries. A great many of Chopin's letters and relics should be burned in a house in which his sister lived at Warsaw in 1863 . The records of more than 50 doctors who observed, treated, advised F. Chopin, or simply were friends with him also were not saved up to now. One of Chopin's biographers, author of the book «Polonaise - The Life of Chopin» Swiss musicologist Guy De Pourtales wrote about that words that could be an epigraph to this article: 
"Of the life of Chopin almost nothing remains. We can discover him therefore only in his music, in a few scraps of correspondence, and in the memories of his friends" [19, p. 10].

The search revealed several publications in which researchers form hypotheses about the direct or indirect manifestations of the influence of F. Chopin's disease in his music. In almost all cases they are talking about B-flat minor sonata, Opus 35. By a strange coincidence, this sonata is the most famous work of F. Chopin due to its movement part - Funeral March. If Chopin had not written anything except Funeral March, he would still be a great composer. Such a successful set of circumstances allows us to hope that there are no gaps in the information concerning this musical work. A comprehensive analysis of the history of the creation of the B-flat minor sonata (professional anamnesis), the circumstances of the composer's life during this time period (anamnesis vitae) and his state of health (anamnesis morbi) will enable us to achieve the proposed goals.

The hypothesis of the Italian scientist Sergio Rocchietta - the author of the book «Musicisti nella vita e nella storia» («Musicians in life and in history») causes the greatest interest. He believed that "Chopin's repetitive coughing attacks are reflected in basic rhythm of his B-flat minor sonata" [20]. The modern Chopin's biographer, the Polish writer Jaroslav Ivashkevich, mentions other musicologists who have discovered "coughing attacks" not only in B-flat minor sonata, but also in Chopin's several preludes [21, p. 216]. Chopin's creative process and Chopin's views on the semantic content of music, the history of the creation of this work and study the opinions of musicologists, should be explored to evaluate the validity of this hypothesis. No one better than F. Chopin himself can answer the question posed in the study.

Acquaintance with the works of F. Chopin shows that the composer did not write program music (type of art music that attempts to musically render an extra-musical narrative) and never supplied his works with comments. Even his variations to the Mozart's opera Don Giovanni Chopin did not consider the musical illustration of the story. Chopin laughed at Schumann's enthusiastic review: "There is no way of guessing what the composer thought when he wrote a piece of music. Don't fantasy on this subject, for the result will be nothing but nonsense of the kind produced by that German who wrote about my variations on La ci darem from Don Giovanni. He said that Don Giovanni kisses Zerlina in D-fiat major. Capital, isn't it?" [22, p. 63]. ("German" Robert Schumann). The composer believed that music should reflect only a person's feelings, his emotional state. In addition, he categorically dismissed any musical imitations. None of his works contain sound imitations of birds singing, the murmur of a stream, or the whiff of a wind. Georges Sand very accurately described the attitude of Chopin to musical imitations: "His genius was full of the mysterious harmonies of nature, translated in his thoughts by sublime musical equivalents and not by a slavish mimicry of out side sounds"
$[19$, p. 174]. For this reason, specialists in medical retrospective diagnostics deny the possibility of using Chopin imitation of the symptoms by musical means [23]. Musicologists hold the same opinion. English biographer Arthur Hadley wrote the following about musicologist discovery in Chopin's music "coughing attacks": "In fact, these fragments should be regarded as a logical development of a purely musical concept and not as a conscious attempt at sound painting" [21, p. 216]. Polish musicologist Danuta Sosnowska (Department of Musicology, Adam Mickiewicz University, Poznań) analyses Fryderyk Chopin's correspondence within the context of the humanities field of body studies. Chopin letters rejects the Romantic lyricisation of sickness; his utterances are pithy, dominated by sarcasm and even physiological brutality, and the style of his description of corporeality employs grotesqueness, irony and absurdity. D. Sosnowska states that neither his illness nor any other experiences of his bodily existence can be treated in an illustrative way that purports to "illuminate" his music directly [24].

Thus, it is safe to exclude a direct reflection of cough or any other symptoms of Chopin's disease in his music (even in the form of stylized imitation). However, this does not mean that the disease did not have an indirect effect on the creation of a musical work.American pianist and music critic of Polish origin, Jan Holcman, author of the book «The legacy of Chopin» devoted an entire chapter of his book to the analysis of the symbolic meaning of F. Chopin's music. From the quotes of F. Chopin, given by Jan Holcman, it is obvious that Chopin was obviously making fun of the critics who discovered mysterious symbols in each of his compositions. Music has been described in beautiful words, but there is little truth in them. Chopin wrote: "Critics who pretend to know everything are ridiculous. These connoisseurs give you scholarly demonstrations of how love or despair was responsible for this or that composition. And if I told them the truth, namely, that I wrote a given piece because it was raining, because I had nowhere to go and was lonely and sad to the point of madness, they would not believe that the rain was merely the occasion. Beethoven may have written the Funeral March simply because he had a stomach ache" [22, p. 64]. Such a statement by F. Chopin, at first glance, encourages the search for an indirect effect of the disease on his music. With this approach, the hypothesis of a professor at the Faculty of Medicine of the National University of Mexico Teresa I. Fortoul van der Goes seems quite realistic: she claims that Ludwig van Beethoven reflected in the fourth part of Symphony No. 2 in $\mathrm{D}$ major the sounds of his gastrointestinal tract: hiccups, belching, flatulence [25]. Indeed, if Chopin believes that'Beethoven may have written the Funeral March simply because he had a stomach ache", then why Chopin could not write B-flat minor sonata (his Funeral March), simply because he had a repetitive coughing attacks? However, Jan Holcman notes that "such descriptions add, perhaps, to the originality of a given piece of music, but they detract from its truth. Fortunately, this literary bath 
into which all the best-known compositions are plunged does not wash off their true characteristics, which the composer has accounted for in an entirely different way, as we shall have occasion to note from Chopin's own report. From his valuable statements it would appear that a composer may write a piece entitled «Wasp» while calmly thinking of a bear. The visions of interpreters who foist on the public associations between a given piece of music and scenes or feelings it supposedly represents, seem ridiculous to Chopin" [22, p. 56]. This characteristic of F. Chopin's own creative method does not contradict the testimony of his biographers.

There is still hope to find a connection between Chopin's music and his most important biographical events (including periods of exacerbation), which should be reflected in his music. However, here we will be disappointed. Holcman J. wrote: "To try to find some sort of symbolic content in every composition is a favorite occupation of critics who frequently establish connections between fragments of compositions and incidents in the composer's personal life. On the basis of the Prelude in A-major Hoesick (one of Chopin's best biographers) "inferred" that Chopin felt at ease in Delphine Potocka's company. Such absurdities are often heard, but in reality music is never biography. A composition may express something or not, but its harmony and rhythm cannot serve as a basis for inferring how the composer felt in someone's company" [22, p.55]. Indeed, in almost all cases it is impossible to trace even the chronological connection between the Chopin's works and the circumstances of their creation: Chopin said that he never knew how a composition he was working on would turn out, or what it would mean. The result was often quite different from the intention. While composing Chopin frequently changed his mind and instead of the work he had initially planned, he composed a different one, combining part of one composition with part of another because they "happened to fit together." It was only due to various and often accidental circumstances that he created works which sound to us (but did not sound to him) unified wholes, products of a single inspiration. Chopin emphatically opposed conjectures of critics "who are trying to find great things which the authors did not even dream of putting in" [22, p. 66]. To top it off, it turns out that F. Chopin numbered his works not in the chronological order of their creation, but in the order of their publication. Furthermore, when forming a certain edition, he personally arranged his works into groups, trying to ensure their compatibility for performing in concerts $[26$, p. 15 ; 27].

The history of the B-flat minor sonata (Opus 35) is a vivid example of Chopin's creative process. Sonata consists of four movements: the first - the sonata allegro, the second - the Scherzo, the third - the Funeral march, the fourth - the final. Sonata published 1840. The first, second and fourth movements were written in 1939. The third part of sonata (the slow movement - Funeral march) according to some biographers had been composed in 1837 [26, p. 131], according to other biographers in 1838 [28, P. 198]. The theme of Funeral march occupies only the fourth part of the third movement of the sonata. It is this part of the third movement B-flat minor sonata that accompanies all the funeral processions since the burial of Chopin himself. Two more themes are completely different in nature and have nothing to do with mourning. This gave grounds for musicologists to argue about the meaning of the Funeral march. The discussion also flared up about Chopin's motivation for connecting four parts into one sonata. For example, Schumann found Chopin's titul "Sonata" capricious and slightly presumptuous, he wrote: "that the idea of calling this work a sonata was a caprice, if not a jest, for Chopin has simply bound together four of his wildest children, to smuggle them under this name into a place to which they could not else have penetrated" [28, P. 199].

There is no consensus about the motivations for writing the Funeral march. Biographer Ferdynand Hoesick, writer, historian of literature, musicologist and publisher, thought that Chopin's Funeral March was written under the influence of the composer's disappointment over Maria Wodzinska [22, p.64]. The only argument of this hypothesis is the coincidence of the estimated time of writing of Funeral March (1837) and parting Chopin with Maria Wodzinska. Chopin suffered because of collapse of the hope of creating a family with his beloved (according to biographers). However, this loss did not affect his work: during 1837-1838, Chopin wrote many magnificent works, completely different in their emotional content: Twelve Etudes (Opus 25); Twenty-four Preludes (Opus 28); Impromptu A flat major (Opus 29); Four Mazurkas (Opus 30); Second Scherzo. B flat minor (Opus 31); Two Nocturnes (Opus 32); Four Mazurkas (Opus 33); the Three Waltzes (Opus 34); Second Ballade in F major (Opus 38). Chopin met George Sand in the spring of 1837, he stayed with her at Nohant in the summer of 1838, and then they had a romantic relationship that lasted for 7 years. If we assume that Funeral March was written in 1838, then all the more we should exclude its connection with the circumstances of the composer's personal life. Most researchers believe that the Funeral march expresses Chopin's feelings about the tragic fate of his own Poland. Franz Liszt heard in the Funeral march the following:"All that the funeral train of an entire nation weeping its own ruin and death can be imagined to feel of desolating woe, of majestic sorrow, wails in the musical ringing of this passing bell, mourns in the tolling of this solemn knell, as it accompanies the mighty escort on its way to the still city of the Dead. The intensity of mystic hope; the devout appeal to superhuman pity, to infinite mercy, to a dread justice, which numbers every cradle and watches every tomb; the exalted resignation which has wreathed so much grief with halos so luminous" [17, p. 28]. Polish biographer Maurycy Karasowski says:"Such a funeral march could only have been written by him in whose soul the pain and grief of the entire nation resounded as an echo" [28, P. 202]. Jeffrey Kallberg, professor of Music History at the University of Pennsylvania, reached a similar conclusion in his study about B-flat minor sonata 
subtatled «Chopin's march, Chopin's death» [29].

Thus, the history of writing B-flat minor sonata confirms the independence of Chopin's work from the circumstances of his personal life. An analysis of the chronological relationship between the writing of the Funeral march and the course of Chopin's disease also showed no dependence. In February 1837, Chopin fell ill with influenza: he had a high fever hemoptysis and hematemesis. He was exhausted and listless, and was confined to his bed for several weeks. Chopin's doctors were unable to determine whether he was suffering from influenza or from consumption. When he recovered, his doctors advised him to go to the spa at Ems. In the summer he made a trip to London. Moscheles and Mendelssohn, who attended Chopin's performances in London, noted that: "He is still suffering and ill". Then he had a letter from Countess Wodzinska, which canceled engagement with Maria [30, p.227]. Chopin suffered a severe exacerbation of the disease during a vacation on Majorca (from November 1838 to February 1839), he had hemoptysis and hematemesis again. Consilium of the three most famous doctors on the island described the condition of Chopin as perilous and gave a disappointing forecast, as Chopin wrote: "The first doctor said that I was dead, the second that I was dying and the third that I would die" [22, p. 90]. Despite this, Chopin continued to write music. George Sand wrote: "In Majorca, while he was mortally ill, he composed music that was full of the parfume of paradise. But I have become accustomed to seeng him in heaven, and I have come to think that in his case being alive or being dead does not matter. He does not quite know himself in which planet he exists; he has no idea of life as we conceive of it and feel it' [30, p.277]. Chopin continued to be ill for months after his arrival from Majorca, but summer 1839 he completed all the compositions for which he had had no energy

\section{References}

1. Cheng TO. Chopin's illness. Chest. 1998;114(2):654-655. doi:10.1378/chest.114.2.654-a.

2. Majka L, Gozdzik J, Witt M. Cystic fibrosis - a probable cause of Frederic Chopin's suffering and death. Journal of applied genetics. 2003;44(1):77-84.

3. Kuzemko JA. Chopin's illnesses. Journal of the Royal Society of Medicine. 1994;87(12):769-772.

4. Wapf V. The disease of Chopin. A comprehensive study of his lifelong suffering. - Moscow: LitRes; 2018. 150 p.

5. Witt M, Szklener A, Marchwica W, Dobosz T. Disease not genetic but infectious: multiple tuberculomas and fibrinous pericarditis as symptoms pathognomonic for tuberculosis of Frederic Chopin. Journal of applied genetics. 2018;59(4):471-473.

6. Charlier P, Perciaccante A, Herbin M, Appenzeller O, Bianucci R. The Heart of Frederic Chopin (1810-1849). The American journal of medicine. 2018;131(4):173-174.

7. Duclos-Vallée JC, Erlinger S. Is Frederic Chopin's Death Elucidated? The American journal of medicine. 2018;131(4):171.

8. Deda J. Pathography of famous composers. Frederik Chopin. Zdravotnicka pracovnice. 1976;26(10):616-621.

9. Wikman B, Persson H, Strandvik B. Frédéric Chopinthe Man, his Illness and his Music. Przeglad Lekarski. 2005;62:321-325. or time in Majorca. They included the Sonata im B-flat minor, Opus 35 (whith the Funeral march); the Impromptu in F-sharp minor, Opus 36; the Two Nocturnes, Opus 37; the third Scherzo in C-sharp minor, Opus 39. He also wrote three new mazurkas in $\mathrm{B}$ major, A-flat major, and C-sharp minor, respectively, which together with that in E-minor composed in Palma, from Opus 41. Professor Axel Karenberg studied the chronological relationship between the course of F. Chopin's disease and the number of works created. He also found that the origin of almost half Chopin's compositions can be traced to the most serious phases of his illness and concluded: "Chopin's suffering had little influence on his creative power. Chopin's determination, motivation, and concentration were so pronounced that he was able to compose brilliantly despite manifold somatic and psychic complaints" [23].

\section{Conclusions}

Thus, the analysis showed the independence of Chopin's work (professional history) both from the circumstances of his personal life (history of life) and from his state of health (history of the disease). Polish biographer, poet and journalist Casimir Wierzynski wrote about Chopin: "In his eyes music was the supreme reality - it was beauty inaccessible to falseness, morality without fragile constraints, a service that was difficult but consecrated to infallibale truth as to divinity" [30, p.234]. This gives grounds to assert that there is not and cannot be any direct or indirect manifestation of disease in Chopin's music. Analysis of Chopin's works provides additional information about his personality and lift the veil of secrecy of his genius, but gives nothing to clarify the diagnosis.

10. Leigh FW. Fryderyc-François Chopin (1810-1849): Music and malady. Journal of medical biography. 2014;22(3):144-152. doi: 10.1177/0967772013511394.

11. Goldberger ZD, Whiting SM, Howell JD. The Heartfelt Music of Ludwig van Beethoven. Perspectives in biology and medicine. 2014;57(2):285-294. doi: 10.1353/ pbm.2014.0013.

12. Van Roessel P, Shafer A. Music, Medicine, and the Art of Listening. Journal for Learning through the Arts. 2006;2(1):14-27. doi:10.21977/d92110074.

13. O'neill D. Allemande l'Asthmatique and Étude Asthmatique. British Medical Journal. 2010;341:5042. doi: https://doi.org/10.1136/bmj.c5042. 1. (French).

14. Evers S. "Tableau de l'operation de la taille". A musical composition by Marin Marais (1725) describing a lithotomy. De Historia Urologiae Europaeae. 1998;5:235-247. (French).

15. Zagvazdin Y. Stroke, music, and creative output: Alfred Schnittke and other composers. Progress in brain research. 2015;216:149-165. doi: 10.1016/bs.pbr.2014.11.006.

16. Gordon F. 'Robert Schumann's mental illnesses. (Genius and madness)', by Mlle Dr Pascal (1908a): Introduction and translation by Felicia Gordon. Hist Psychiatry. 2015;26(3):359-371. doi:10.1177/0957154X15589457. (German). 
17. Liszt F. Life of Chopin. New York: C. H. Ditson \& Co; $1880,202 \mathrm{p}$.

18. Karenberg A. Retrospective diagnosis: use and abuse in medical historiography. Prague Med. Rep. 2009;110(2):140-145.

19. De Pourtales G, author; Bayly Ch, transl. Polonaise-The Life of Chopin. New York: Henry Holt and Co; 1863. 350 p.

20. Contribution of psychoanalysis to musicology. I. Chopin. Minerva medica. 1951;42(83):706-708.

21. Ivashkevich Ja. Shopen. Moskva: Molodaja gvardija; 1963. 301 p. (Russian).

22. Holcman J. The legacy of Chopin. New York: Philosophical library; 1954. $128 \mathrm{p}$

23. Karenberg A. Chopin's misery and musicians' medical biography. Sudhoffs Archiv. 2007;91(1):82-98. doi: $10.2307 / 20778050$.

24. Sosnowska D. Fryderyk Chopin's correspondence from the perspective of body studies. The discovery of corporeality.
Interdisciplinary Studies in Musicology. 2010;9:265-281.

25. Fortoul T. La música en la medicina y la medicina en la música Parece, pero no es lo mismo. Revista de la Facultad de Medicina. 2016;59(5):57-60. (Spanish).

26. Brown MJE. Chopin: an index of his works in chronological order. Boston: Da Capo Press; 1972. 214 p.

27. Kallberg J. Compatibility in Chopin's Multipartite Publications. Journal of Musicology. 1983;II(4):391-417.

28. Jonson ACG. A handbook to Chopin's works giving a detailed account of all the compositions of chopin, short analyses for the piano student, and critical quotations from the writings of well-known musical authors. London: W. Reeves; 1908, 300 p.

29. Kallberg J. Chopin's march, Chopin's death. 19th-Century Music. 2001;25(1):3-26. doi:10.1525/ncm.2001.25.1.3.

30. Wierzynski C. Translated from Polish by Nortbert Guterman. The life and death of Chopin. New York: Simon and Schuster; 1949. 485 p.

\section{СЛУЧАЙ ФРЕДЕРИКА ШОПЕНА: МОЖЕТ ЛИ МУЗЫКА БЫТЬ СИМПТОМОМ? \\ ${ }^{1}$ Березуцкий В. И., ${ }^{2}$ Березуцкая М. С. \\ ${ }^{1}$ Днепропетровская медииинская академия МЗ Украины, Днепр, Украина \\ ${ }^{2}$ Днепропетровская академия музыки им. М. Глинки, Днепр, Украина}

Введение. Тайна болезни и смерти великого польского композитора Фредерика Шопена еще не разгадана окончательно. Многочисленные попытки ретроспективной диагностики использовали все имеютиеся возможности, кроме анализа музыки композитора для поиска в ней проявлений его болезни. В истории музыки и медицины есть много примеров того, что музыкальные шедевры содержат признаки болезни автора.

Цель. Целью данного исследования является поиск признаков проявления болезни Шопена в его музыкальных произведениях.

Материал и методы. Кореспонденциия Фредерика Шопена, работь наиболее авторитетных биографов композитора, а также научные публикации, посвященные изучению обстоятельств жизни, болезни и творчества Шопена. В базах данных Scopus, WebOfScience, MedLine и PubMed поиск источников проводился без ограничений по времени. Обнаруженные публикации были подвергнуты медицинскому и музыковедческому анализу.

Выводы. Анализ показывает, что творческий проиесс Фредерика Шопена не зависел ни от обстоятельств его личной жизни, ни от его здоровья. Композитор не писал программную музыку, никогда не снабжал свои произведения комментариями и не применял имитацию звука музыкальными средствами. Ни одна из гипотез о том, что приступы кашля отражены в музыке Шопена, не была подтверждена.

Ключевые слова: Фредерик Шопен, анамнестическая диагностика, ретроспективная диагностика.

Для цитирования: Berezutsky, V. I. Case of Frederic Chopin: could music be a symptom? / V. I. Berezutsky, M. S. Berezutskaya // Журнал Гродненского государственного медицинского университета. 2020. T. 18, № 2. C. 211-216. http:// dx.doi.org/10.25298/2221-8785-2020-18-2-211-216

Конфликт интересов. Авторы заявляют об отсутствии конфликта интересов.

Conflict of interest. The authors declare no conflict of interest.

Об авторах / About the authors

*Березуцкий Владимир / Berezutsky Vladimir, e-mail: berezut@ua.fm, ORCID: 0000-0002-0989-2960

Березуцкая Марина / Berezutskaya Maryna, e-mail: berezut@ua.fm, ORCID: 0000-0002-5511-2195

* - автор, ответственный за переписку / corresponding author

Поступила / Received: 19.11.2019

Принята к публикаичи / Accepted for publication: 20.03.2020 